\title{
ИСПОЛЬЗОВАНИЕ ВЫСОКОТЕМПЕРАТУРНОЙ ГЕЛЬ-ПРОНИКАЮЩЕЙ ХРОМАТОГРАФИИ В ИССЛЕДОВАНИИ ПОЛИМЕРОВ \\ В ПАО «КАЗАНЬОРГСИНТЕЗ»
}

Фазылзянов А.Р., Назипов М.Р., Марянина Е.В., Ананьева Г.С.

ПАО «Казаньоргсинтез», Казань, Россия

clo@kos.ru

DOI: 10.26902/ASFE-11_135

В данной работе речь пойдет о применении в ПАО «Казаньоргсинтез» метода гельпроникающей хроматографии (ГПХ). Измеряемые методом ГПХ средние молекулярные массы, молекулярно-массовое распределение (ММР) и параметры разветвленности позволяют достаточно оперативно оценивать влияние изменений в технологических (производственных) параметрах на молекулярно-массовые характеристики полимера и, соответственно, на физико-механические свойства полимера, и, его качество. Кроме того, сочетание метода высокотемпературной ГПХ с другими физико-химическими методами анализа (термоанализ, ИК-спектроскопия) и изучение реологических и физико-механических характеристик с применением испытательного оборудования позволяет точно и уверенно контролировать технологический процесс производства полимеров в ПАО «Казаньоргсинтез».

В приборе фирмы Agilent 1260 Infinity II HT GPC в систему, помимо дифференциального рефрактометра и проточного вискозиметра, добавлен двуугловой детектор по светорассеянию. Это позволило оценивать радиус инерции молекулы $R_{\mathrm{g}}$ методом светорассеяния, что придает хроматографической системе следующие положительные моменты:

a) прямое измерение радиуса инерции молекулы $R_{\mathrm{g}}$, а следовательно, и абсолютного молекулярного веса, вносит дополнительные поправки в определение средних молекулярных масс и ММР полимеров, делая данное определение более точным;

б) позволяет анализировать полимеры, для которых трудно подобрать узкие стандарты для калибровки, например - эластомеры (полибутадиен).

На рис.1-2 показаны, соответственно, интегральное и дифференциальное ММР и закон вязкости (теоретический и экспериментальный) для полиэтилена марки ПЭ2НТ11-285Д, произведенного в ПАО «Казаньоргсинтез». Закон вязкости практически линеен и совпадает с теоретическим законом, поскольку образец не обладает ДЦР.
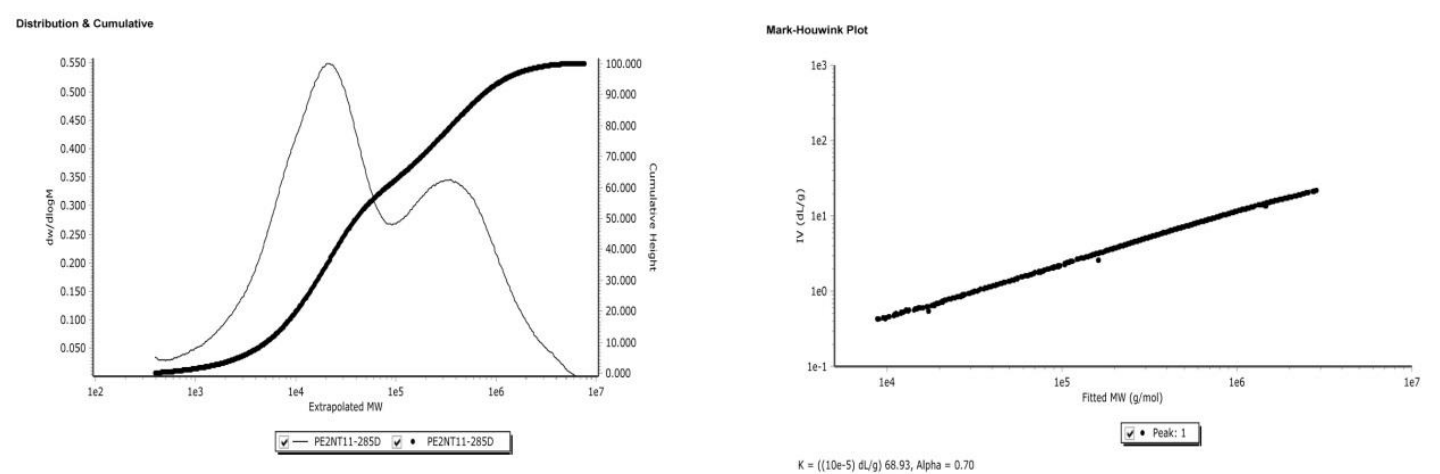

Кроме того, из рис.1 видно, что использование метода ГПХ дает возможность устанавливать мультимодальность исследуемых образцов, что особенно актуально в связи с увеличением производства и разработки новых типов полиэтилена (марок) с мультимодальным распределением. 